\title{
REGULATED DEFICIT IRRIGATION AND DIFFERENT MULCH TYPES ON FRUIT QUALITY AND YIELD OF WATERMELON ${ }^{1}$
}

\author{
KLEITON ROCHA SARAIVA ${ }^{2 *}$, THALES VINÍCIUS DE ARAÚJO VIANA ${ }^{3}$, FRANCISCO MARCUS LIMA \\ BEZERRA $^{3}$, SOLERNE CAMINHA COSTA ${ }^{4}$, RUBENS SONSOL GONDIM $^{5}$
}

\begin{abstract}
The objective of this work was to assess the pulp resistance, soluble solids and yield of watermelon fruits grown under different irrigation managements (determined by the ISAREG model) and mulches, and their interactions. After a survey carried out on local producers, two experiments were conducted, using a completely randomized block design in split-plot arrangement with four replications, in the Teaching, Research and Extension Unit (UEPE) of the Federal Institute of Ceara (IFCE), Jaguaribe-Apodi Irrigation District (DIJA), State of Ceara, Brazil. The treatments consisted of four irrigation managements in the plots, M1 (100\% of the available-water capacity (AWC) of the soil), M2 (80\%), M3 (60\%) and M4 (average water depth used by local producers) and four mulch types in the sub-plots, without mulching $(\mathrm{C} 0)$ with rice husk (C1), white plastic (C2) and black plastic (C3) as mulches. The results were subjected to analysis of variance, and significant results were subjected to regression (irrigation managements), average test (mulches) and trend graphs (interaction between the factors). The irrigation management practiced during the watermelon crop cycle by the local producers of the Irrigation District of Jaguaribe-Apodi (DIJA) in the State of Ceara, Brazil, is not appropriated, since they usually apply more water than the highest water depth determined by the ISAREG model (100\% of the AWC). The plants grown under irrigation water depth of $365.20 \mathrm{~mm}$ (M1) and soils with mulches of rice husk or white plastic had the highest yields and fruits with better quality of soluble solids and pulp resistance.
\end{abstract}

Keywords: Water deficit. Isareg model. Citrullus lanatus. Mulching.

\section{ASPECTOS PRODUTIVOS DA MELANCIEIRA SOB IRRIGAÇÃO COM DÉFICIT E DIFERENTES COBERTURAS UTILIZANDO O MODELO ISAREG}

\begin{abstract}
RESUMO - Objetivou-se avaliar a resistência de polpa e os sólidos solúveis dos frutos, e a produtividade da melancieira, sob diferentes proposições de irrigação (geradas pelo ISAREG) e condições de cobertura do solo; e seus efeitos de interação. Após pesquisa de campo junto aos irrigantes foram realizados dois experimentos na UEPE (Unidade de Ensino, Pesquisa e Extensão) do IFCE, no Distrito de irrigação Jaguaribe-Apodi, DIJA, sob delineamento em blocos completos ao acaso, com parcelas subdivididas e quatro repetições. Os tratamentos consistiram da combinação de quatro proposições de irrigação (M1 - manutenção de $100 \%$ da capacidade de água disponível no solo (CAD); M2 - $80 \%$; M3 - 60\%; e M4 - lâmina modal dos irrigantes) nas parcelas, e quatro sub-parcelas, compostas por três condições de cobertura no solo (coberturas com casca de arroz, com "mulching” branco e com "mulching" preto, denominadas C1, C2 e C3), e uma sem cobertura, denominada C0. Os resultados foram submetidos à análise de variância e quando significativos, à regressão (lâminas), a teste de médias (coberturas) e a gráficos de tendência (interação entre os fatores). Concluiu-se que os irrigantes não praticam o manejo correto da irrigação, pois aplicam, durante todo o ciclo da melancia, mais água do que a indicação de maior lâmina do ISAREG (100\% da CAD). As plantas irrigadas pela lâmina M1 em solo coberto por casca de arroz e "mulching” branco demonstraram melhores características produtivas e de pós-colheita.
\end{abstract}

Palavras-chave: Déficit hídrico. Software. Citrullus lanatus. Coberturas no solo.

\footnotetext{
*Corresponding author

${ }^{1}$ Received for publication in 03/04/2016; accepted in 09/08/2016.

Paper extracted from the doctoral thesis of the first author.

${ }^{2}$ Department of Agriculture, Instituto Federal do Piauí, Campo Maior, PI, Brazil; kleiton.rocha@ifpi.edu.br.

${ }^{3}$ Department of agricultural engineering, Universidade Federal do Ceará, Fortaleza, CE, Brazil; thales@ufc.br, mbezerra@ufc.br

${ }^{4}$ Department of Agronomy, Instituto Federal do Ceará, Limoeiro do Norte, CE, Brazil; solernecosta@gmail.com.

${ }^{5}$ Sector of thematic nuclei, Empresa Brasileira de Pesquisa Agropecuária - Agroindústria Tropical, Fortaleza, CE, Brazil; rubens.gondim@embrapa.br.
} 


\section{INTRODUCTION}

The increasing water scarcity due to population growth, irregular precipitation and economic development is increasing challenging the agriculture and requiring new solutions for water management in irrigated areas, especially in the Brazilian semiarid region, in which the water is limited. Moreover, in the semiarid region (Northeast of Brazil), the irrigation management is not appropriated (SARAIVA et al., 2013), usually with application of more water than the crop needs, causing waste of water resources, which are scarce in this region.

A rational management of irrigation aims to maximize the water use efficiency and maintain a favorable soil moisture to plants, taking into account the climatic conditions of the crop location and its characteristics. Thus, the rational management of irrigation seeks meet the water needs of crops, providing water at the right time and correct amount, without waste (PEREIRA, 2004).

The regulated deficit irrigation is one of the management strategies adopted by producers aiming to achieve high yields without the soil to reach field capacity (LÉO; HERNANDEZ, 2007).

The use of computer software in the irrigation management to calculate the water requirements for crops from climate, soil and crop data is one of the strategies to avoid water waste (PEREIRA, 2004). The ISAREG model (Institute of Agronomy, Portugal) is a simulation software of soil water balance considering the water rising by capillarity and percolation through the root zone. This model has been used in several countries as a new technology for irrigation management, which simulates water depths, aiming to maintain the soil moisture at different maximum storage percentages of available-water capacity (AWC) of the soil.

Mulching is also a strategy to decrease water use in agriculture, since it is a simple technology that benefits the crop production and yield, especially under low water availability, decreasing the frequency of phytosanitary measures, and consequently, the production costs.

Moreover, the interaction between regulated deficit irrigation (ISAREG model) and mulching may increase crop yield and decrease water use. The water depth determined by the ISAREG model for maintaining a bare soil moisture at percentages below the AWC may be sufficient to keep a soil with mulching at $100 \%$ of the $\mathrm{AWC}$, due to the lower evaporation in this condition.

Therefore, the objective of this work was to assess the pulp resistance, soluble solids and yield of watermelon fruits grown under different irrigation managements (determined by the ISAREG model) and mulches, and their interactions.

\section{MATERIAL AND METHODS}

The experiments were performed in the Teaching, Research and Extension Unit (UEPE) of the Federal Institute of Ceara (IFCE), Jaguaribe-Apodi Irrigation District (DIJA), Limoeiro do Norte, State of Ceara, Brazil $\left(05^{\circ} 06^{\prime} 3^{\prime \prime S}\right.$; $37^{\circ} 52^{\prime} 21^{\prime \prime} \mathrm{W}$; altitude of $145.95 \mathrm{~m}$ ). The region climate is BSw'h', semiarid, according to the Köppen classification.

Two consecutive experiments (two cycles) were conducted on crops of watermelon (Citrullus lanatus), variety Crimson Sweet. All methodologies and analyzes in both cycles were the same, except the water depths (simulated by the ISAREG model), which was different due to the different periods (months) of the cycles.

The data input in the ISAREG for the simulation process were from local researches on the soil physical characteristics (moisture at field capacity and wilting point), crop phenological stages [which are well-defined as Stage 1 (planting to first irrigation - 2 days), Stage 2 (early vegetative growth - 16 days), Stage 3 (total soil cover and flowering - 10 days), Stage 4 (fruit formation - 21 days), Stage 5 (leaf senescence - 14 days) and Stage 6 (harvest and end of the crop cycle - 4 days)] and water availability factor (f) and root system effective depth (Z) of each phenological stage. This model also required input of data on the water management, thus, three irrigation managements determined by the ISAREG $(60 \%, 80 \%$ and $100 \%$ of the AWC) and one from the local producers in the DIJA (average water depth of $6.3 \mathrm{~mm} \mathrm{day}^{-1}$ during the watermelon cycle) were used.

The experiments were conducted using a completely randomized block design in split-plot arrangement $(4 \times 4$, totaling 16 sub-plots $)$ with four replications. The treatments consisted of four irrigation managements in the plots, M1, M2 and M3 (determinate by the ISAREG model) and M4 (average water depth used by local producers) and four mulch types in the sub-plots, without mulching $(\mathrm{C} 0)$ with rice husk $(\mathrm{C} 1)$, white plastic $(\mathrm{C} 2)$ and black plastic $(\mathrm{C} 3)$ as mulches.

The irrigation managements determined by the model ISAREG resulted in the treatments M1, optimal irrigation management using the water depth needed to maintain a bare soil at maximum storage capacity, $100 \%$ of the $\mathrm{AWC}$, without percolation; $\mathrm{M} 2$, irrigation management using the water depth needed to maintain a bare soil at approximately $80 \%$ of the $\mathrm{AWC}$; and $\mathrm{M} 3$, irrigation management using the water depth needed to maintain a bare soil at approximately $60 \%$ of the AWC. The treatment M4 consisted of an irrigation management using the average water depth of $6.3 \mathrm{~mm} \mathrm{day}^{-1}$, which is used by the local producers in the DIJA.

The mulch treatments consisted of a $2-\mathrm{cm}$ layer of rice husk $(\mathrm{C} 1)$, which is easily acquired in 
the region, spread over $0.5 \mathrm{~m}^{2}$ around the plants, totaling a volume of approximately 10 liters per plant; mulching treatments with black/white low-density polyethylene films, used with the white (C2) and black (C3) face exposed, also covering an area of $0.5 \mathrm{~m}^{2}$ around the plants; and a treatment without mulching $(\mathrm{C} 0)$ as control.

The watermelon crop was planted with spacing of $2.0 \times 0.5 \mathrm{~m}$, with each sub-plot consisting of 6 plants, totaling $6.0 \mathrm{~m}^{2}(2.0 \times 3.0 \mathrm{~m})$, from which the 4 central plants was used for evaluations.

Border rows were planted between the treatment rows, totaling nine rows per block $(9 \times 2.0 \mathrm{~m}=18.0 \mathrm{~m}$ wide $)$. Each block consisted of an area of $216.0 \mathrm{~m}^{2}(18.0 \times 12.0 \mathrm{~m}$ long). The total area of the experiment was $864.0 \mathrm{~m}^{2}(18.0 \times 48.0 \mathrm{~m})$.

The sowing of the first (August 15, 2012) and second (November 12, 2012) crop cycle was carried out in 128-cell polystyrene trays with a commercial substrate (PlantMax). The transplanting was carried out in August 22 (first cycle) and November 19, 2012 (second cycle).

Mineral fertilization was performed based on soil analysis, aiming to supply the crop macro and micronutrient needs, using fertigation with application frequency based on Fernandes et al. (2014), who reported good results using daily fertigation applications during the watermelon cycle. Thus, the fertigation was carried out on the transplanting day and finished at 50 DAT (days after transplanting), which consisted of $22.6 \mathrm{~kg}$ of $\mathrm{N}$ (urea), $43.3 \mathrm{~kg}$ of $\mathrm{K}_{2} \mathrm{O}$ (potassium chloride), $38 \mathrm{~L}$ of $\mathrm{P}_{2} \mathrm{O}_{5}$ (phosphoric acid), $1.7 \mathrm{~kg}$ of $\mathrm{Zn}$ (zinc sulfate) and $0.85 \mathrm{~kg}$ of $\mathrm{B}$ (boric acid).

Weed control was performed during the crop cycle, with hoeing between rows and manual weeding near the plants. The pests and diseases that occurred during the watermelon cycle (whitefly, cochineal and fungi) were managed with insecticides and fungicides.

The harvests started in October 28, 2012 (first cycle) and January 25, 2013 (second cycle), when the fruits reached physiological maturity point, i.e., minimum ${ }^{\circ}$ Brix around 8 and nearest tendril to the fruit dried, which was evaluated in the field with a portable refractometer.

The periodic harvests were carried out five days apart, from 67 DAT, with two harvests considering the commercial fruits, those over $3.0 \mathrm{~kg}$, normal shape and without external or internal deterioration.

The crop irrigation was carried out daily during the watermelon cycle, by a localized drip system, with one emitter line per plant row. Pressure-compensating emitters were used, with average flow rate of $2.3 \mathrm{~L} \mathrm{~h}^{-1}$, and operating pressure of $300 \mathrm{kPa}$.

The daily amounts of water applied followed the irrigation managements determined by the
ISAREG model and the average water depth (WD) used by the local producers in the DIJA. The crop evapotranspiration (ETc) data input to the ISAREG were from local experiments, through the soil water balance methodology; the reference evapotranspiration (ETo) was estimated by the Penman-Monteith/FAO method, as described by Allen et al. (1998), with climatological variables data from a local weather station; and the crop coefficient $(\mathrm{Kc})$ was calculated by the ratio between the ETc and ETo. The average Kc used were from previous experiments conducted in the same area on watermelon, whose values were according to each phenological stage, 0.32 (Stage 1), 0.33 (Stage 2), 0.56 (Stage 3), 1.30 (Stage 4), 1.04 (Stage 5) and 0.76 (Stage 6).

The daily time of irrigation used was determinate according to the water depth used in each

(Equation $T i=\frac{W D_{I} * S_{R} * S_{E} * F m}{I_{e} * q_{E}} \quad 1$ ),

in which $\mathrm{Ti}$ is the time of irrigation (hours), WD is the water depth of the treatment ${ }_{i}$ determined by the ISAREG model, $\mathrm{S}_{\mathrm{R}}$ is the spacing between irrigation rows $(2.0 \mathrm{~m}), \mathrm{S}_{\mathrm{E}}$ is the spacing between emitters $(0.5 \mathrm{~m}), \mathrm{Fm}$ is the mulching factor (dimensionless), Ie is the irrigation efficiency (dimensionless; 0.95) and $\mathrm{q}_{\mathrm{E}}$ is the emitter flow $\left(2.3 \mathrm{~L} \mathrm{~h}^{-1}\right)$.

The mulching factor $(\mathrm{Fm})$ in the watermelon cycle was used according to the results reported by Miranda et al. (2004). The Fm ranged from 0.33 to 1.00 (stage of the crop maximum water requirement) during the first crop cycle, with $\mathrm{Fm}=0.33$ (1 to 29 DAT), 0.35 to 0.98 (30 to 55 DAT), and 1.00 (56 to 67 DAT).

Tensiometers were installed $20 \mathrm{~cm}$ deep in the soil for monitoring moisture in the average depth of the watermelon root system effective area.

The variables evaluated were the average yield (AY), through the average fruit weight and number of fruits per plant divided by the experimental area and extrapolate to $\mathrm{Kg} \mathrm{ha}^{-1}$; fruit quality, through the fruit soluble solids (SS) at harvest, using a portable refractometer $\left(0-32{ }^{\circ} \mathrm{Brix}\right)$ in the juice from macerated pulp of four fruits; and pulp resistance to penetration (PR), expressed in Newton $(\mathrm{N})$, assessed with a fruit penetrometer.

The data resulting from the evaluations of the characteristics and their interactions were subjected to analysis of variance (ANOVA) and, when significant by the $\mathrm{F}$ test, the data were subjected to the Tukey's test at $1 \%$ and $5 \%$ of probability for the qualitative factor (mulches), and to regression analysis for the quantitative factor (water depths). 


\section{RESULTS AND DISCUSSION}

First watermelon crop cycle
The analysis of variance showed significant effects $(p<0.01)$ of the interaction between water depths and mulches on the pulp resistance (PR), soluble solids (SS) and average yield (AY) (Table 1).

Table 1. Analysis of variance and level of significance by the Tukey's test for the variables pulp resistance (PR), soluble solids (SS) and average yield (AY) of the first watermelon crop cycle.

\begin{tabular}{llccc}
\hline \multirow{2}{*}{ Source of variation } & \multirow{2}{*}{$\mathrm{DF}$} & \multicolumn{3}{c}{ Mean Square } \\
\cline { 3 - 5 } & & $\mathrm{PR}$ & $\mathrm{SS}$ & $\mathrm{AY}$ \\
\hline Water depths (WD) & 3 & $111.59896^{* *}$ & $1.52083^{*}$ & $511.02042^{* *}$ \\
Residue (a) & 12 & 0.60938 & 0.40625 & 0.94094 \\
Mulches (M) & 3 & $21.72396^{* *}$ & $3.35417^{* *}$ & $2171.01042^{* *}$ \\
Interaction AxB & 9 & $59.12674^{* *}$ & $1.59028^{* *}$ & $118.92333^{* *}$ \\
Residue (b) & 36 & 0.48438 & 0.42014 & 0.61455 \\
Total & 63 & - & - & - \\
\hline CV \% (WD) & - & 4.35 & 6.87 & 1.58 \\
\hline CV \% (M) & - & 3.88 & 6.98 & 1.28 \\
\hline
\end{tabular}

$\mathrm{DF}=$ Degree of freedom; $\mathrm{CV}=$ Coefficient of variation; $*=$ significant at $5 \%$ and $* *=$ significant at $1 \%$ by the Tukey's test.

The pulp resistance (PR) presented a applied, regardless of the use of mulching (Figure 1). decreasing linear response to the amount of water

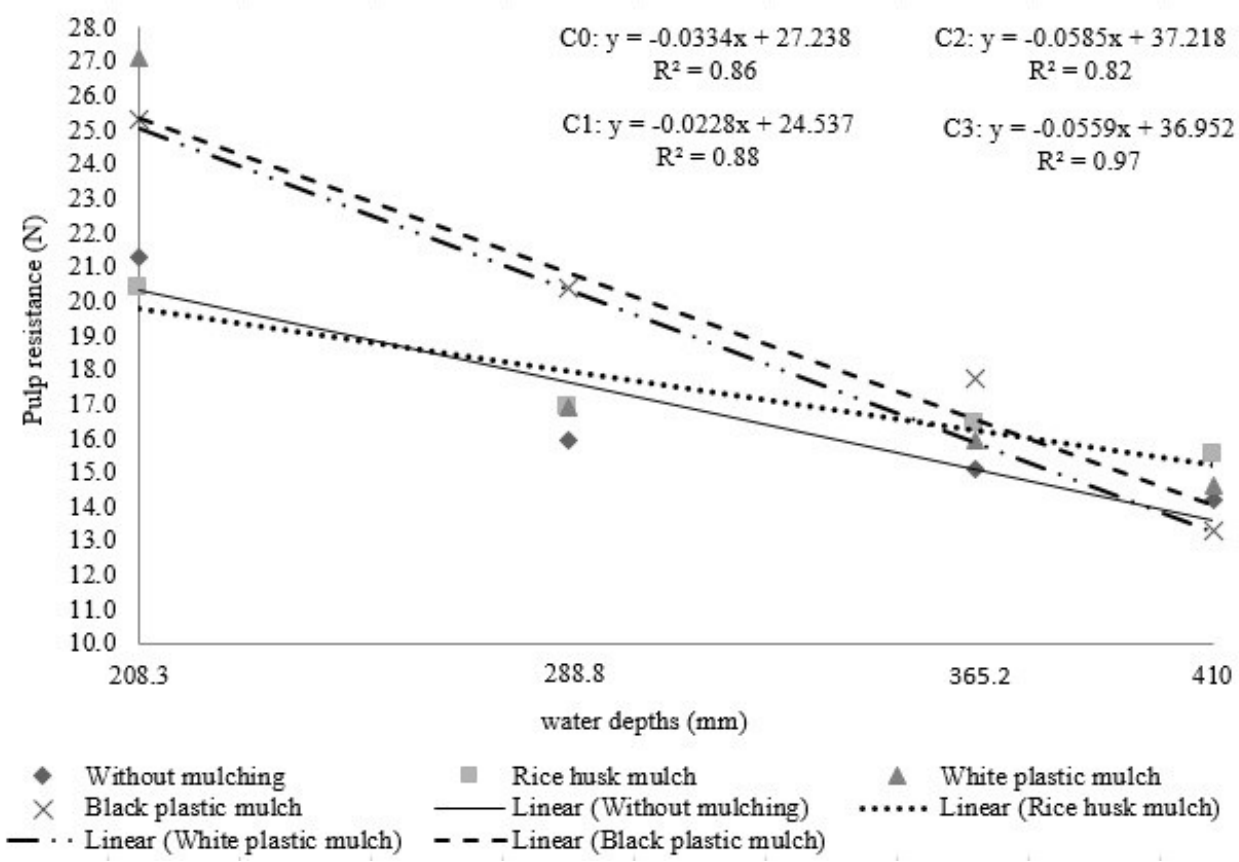

Figure 1. Effects of water depths and mulches on the fruit pulp resistance (PR) during the first watermelon crop cycle.

The fruits from plants that received greater amount of water had lower PR (Figure 1). Silva et al. (2008) evaluated PR of watermelon fruits depending on water depths and reported that, the greater the amount of water applied, the lower the fruit pulp resistance. Moreover, Lacerda (2007) found a direct correlation between PR and plant water, since the water in the plant cell is responsible for maintaining its turgidity, contributing to the growth and maintenance of the plant tender tissues form and structure.
The highest PR values $(25.3 \mathrm{~N})$ were found in fruits from plants whose soil mulching was $\mathrm{C} 3$ (black plastic). This result may be due to this plastic film to reduce soil moisture by heat absorption, causing lower water availability to the plant and lower amount of water translocated through the fruit cell wall, resulting in higher PR.

The highest PR values in the treatment M2 $(288.8 \mathrm{~mm})$ was found on plants whose soil mulching was C3 $(20.4 \mathrm{~N})$ and for the treatment M4 $(410 \mathrm{~mm})$ with $\mathrm{C} 1$ (rice husk) $(15.5 \mathrm{~N})$. Barros et al. 
(2012) evaluated a watermelon crop in the State of Roraima, Brazil, with a similar water depth and found an average PR of $20 \mathrm{~N}$.

The combination M3 (208.3 mm) with the mulch $\mathrm{C} 2$ (white plastic) presented the highest PR $(27.1 \mathrm{~N})$, thus, the effect of the soil moisture on the $\mathrm{PR}$ is noticeable, since the fruits from plants whose soil received lower amounts of water had the greatest PR. Silva et al. (2008) found average PR of $13.0 \mathrm{~N}$ with similar water depths to M3, however, in soil without mulching.

The soluble solids (SS) presented a decreasing linear response to the amount of water applied, regardless of the use of mulching (Figure 2).

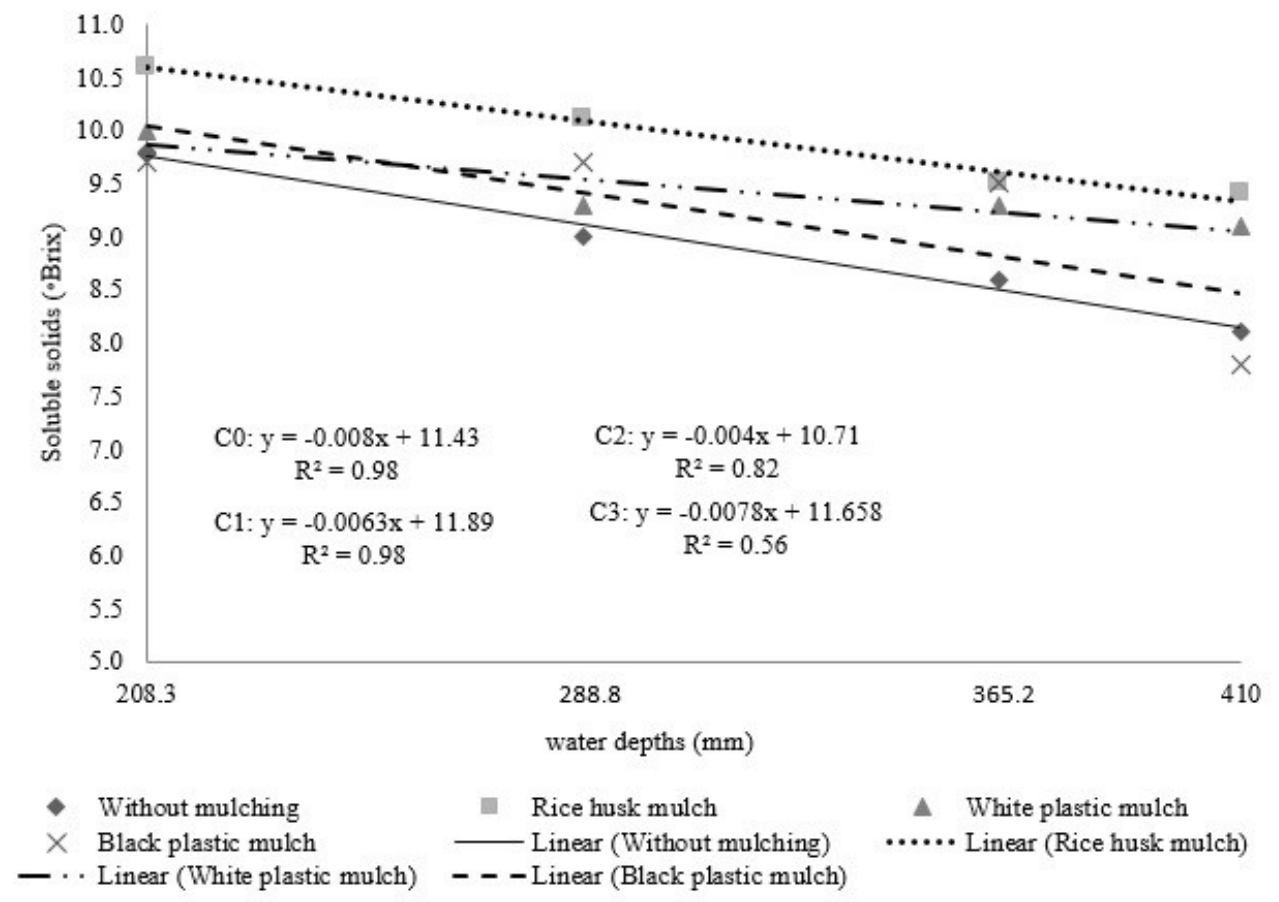

Figure 2. Effects of water depths and mulches on the fruit soluble solids (SS) during the first watermelon crop cycle.

Therefore, greater amounts of water decrease the SS of the watermelon pulp, confirming the results reported by Andrade Júnior et al. (2007), who found decreasing sugars contents and fruit skin cracks due to the excess of water, making the fruit bland. According to Sousa et al. (2011), the watermelon water requirement during the maturation stage decreases about $25 \%$ to $30 \%$ compared with the preceding stage, thus, a decrease in the amount of water applied is critical for optimizing the fruit soluble solid contents.

The treatment with the lowest water depth (M3) presented better SS results with the rice husk mulch $(\mathrm{C} 1)\left(10.6^{\circ} \mathrm{Brix}\right)$, confirming the satisfactory action of the mulching and direct effect of the water depth applied to the watermelon crop. On the other hand, Silva, Cunha and Felipe (2014) evaluated an irrigated watermelon crop subjected to different mulches (black plastic, maize straw and carnauba straw) and found an average of $7.8^{\circ}$ Brix. The lowest ${ }^{\circ}$ Brix values in M3 were found with the mulches $\mathrm{C} 3$ and $\mathrm{C} 0$ (without mulching). The treatments $\mathrm{M} 1$ (365.2 mm), M2 and M4 produced fruits with higher ${ }^{\circ}$ Brix with the mulch $\mathrm{C} 1$.

The combination M4C3 resulted in fruits with the lowest ${ }^{\circ}$ Brix (7.8). Ramos, Dias and Aragão (2009) reported average ${ }^{\circ}$ Brix of 8.3 , and Carlos et al. (2002) evaluating watermelon post-harvest, found average ${ }^{\circ}$ Brix of 10.6 .

Similar to most of the variables evaluated, the mulches $\mathrm{C} 1$ and $\mathrm{C} 2$ showed the best SS results, with the highest ${ }^{\circ}$ Brix, while the lowest values were found in the treatment without mulching, indicating that this is an advantageous technic in watermelon crops.

The average yield (AY) presented a quadratic polynomial response to the amount of water applied, regardless of the use of mulching (Figure 3 ).

The interactions between water depths and mulches showed, to a certain extent (M1 and M4), that the average watermelon yield increases with increasing amounts of water applied, regardless of the type of mulch. This result was also found by Batista et al. (2008), who evaluated watermelon water deficit and found higher yields in treatments without water deficit. Oliveira et al. (2012), reported that this result is associated with the maintenance of an adequate water content in the soil for the crop, enabling a greater water and nutrient absorption, which is responsible for increase the photoassimilates translocated from the leaves to reproductive organs, increasing the production.

The treatment M1 had the highest fruit yield (77.0 Mg ha ${ }^{-1}$ ) with the mulch $\mathrm{C} 2$, confirming again the importance of using this mulch for irrigated watermelon crops. 


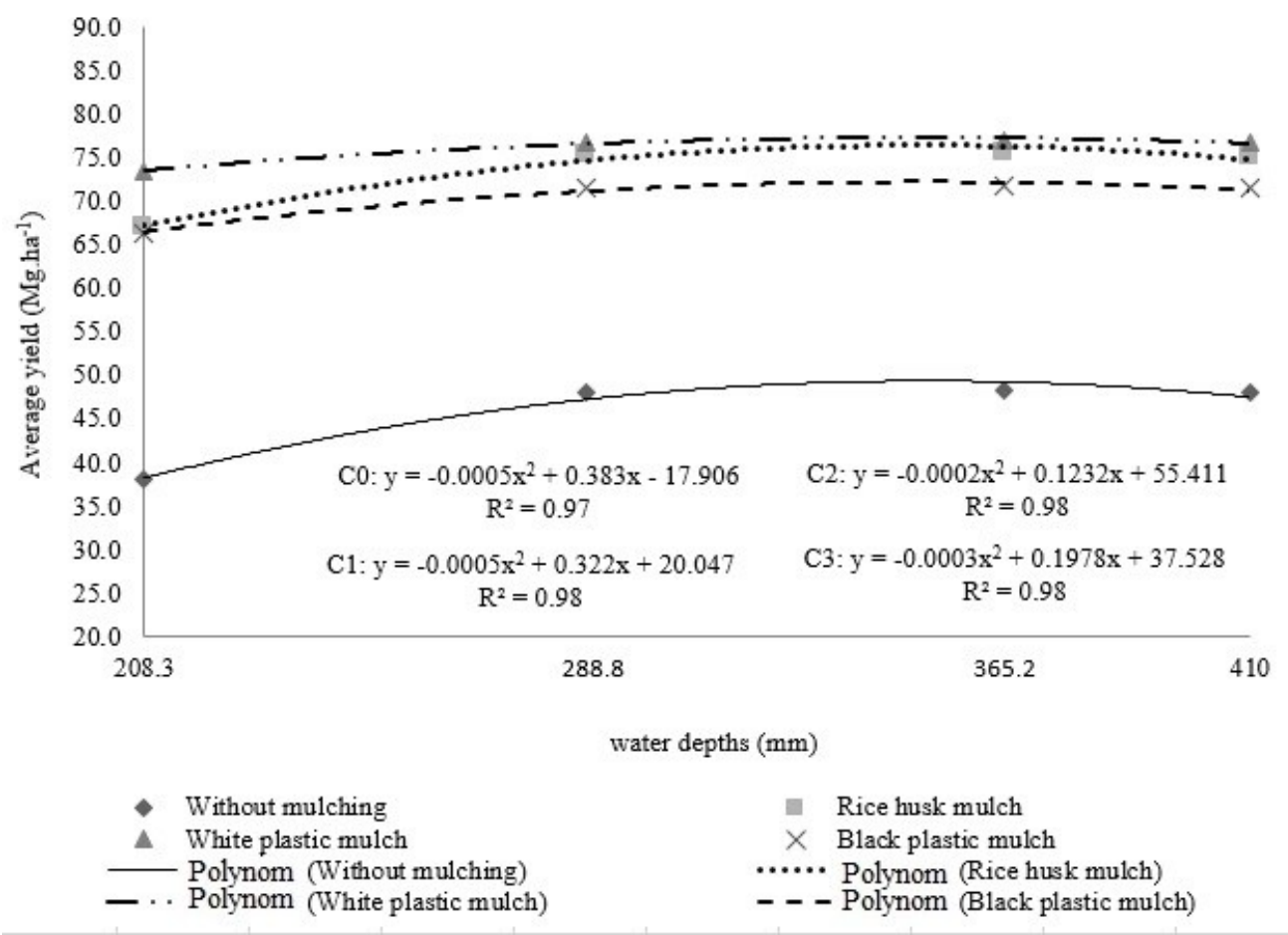

Figure 3. Effects of water depths and mulches on the fruit average yield (AY) during the first watermelon crop cycle.

The yield equation of the treatments with mulch C2 indicated a maximum yield of $74.38 \mathrm{Mg} \mathrm{ha}^{-1}$, with a water depth application of $308 \mathrm{~mm}$. Ramos, Dias and Aragão (2009), evaluated productive characteristics of irrigated watermelon and found average yield of $76.1 \mathrm{Mg} \mathrm{ha}^{-1}$. The lowest yield in M1 was found with the mulch $\mathrm{C} 0$.

The greatest yields in the treatments M4, M2 and M3 was also with the mulch $\mathrm{C} 2$, especially because of the moisture retention in the soil, resulting in moistures $\left(0.33\right.$ to $\left.0.42 \mathrm{~cm}^{3} \mathrm{~cm}^{3}\right)$ greater than that found in the $\mathrm{C} 0\left(0.31 \mathrm{~cm}^{3} \mathrm{~cm}^{3}\right)$. This result indicates a positive correlation between the mulch $\mathrm{C} 2$ and the increase in watermelon crop yield in the DIJA. According to Carvalho, Bezerra and Carvalho (2007), the water reduction in certain phenological phases can substantially contribute to decrease the watermelon yield.

The combination $\mathrm{M} 3 \mathrm{C} 0$ resulted in the lowest yield $\left(38 \mathrm{Mg} \mathrm{h}^{-1}\right)$. This result has a physiological explanation. According to Azevedo et al. (2005), water deficit causes significant decrease in physiological activities, especially cell division and growth, and consequently, plant growth. This deficiency also causes stomatal closure, which reduces the intracellular $\mathrm{CO}_{2}$ concentration, decreasing its assimilation and the crop production.

The mulches $\mathrm{C} 2, \mathrm{C} 1$ and $\mathrm{C} 3$ contributed to better results of watermelon yield, in descending order, showing that mulching is an advantageous technique for watermelon crops in the DIJA.

Mulching techniques using polyethylene films have improved growth and yield, for example, of arugula (Eruca sativa) and watermelon crops (CANTU et al., 2013; MORAIS et al., 2008). Moreover, the efficiency of mulches combined with ISAREG simulations of regulated deficit irrigation, are increasingly effective for irrigation managements.

\section{Second watermelon crop cycle}

The analysis of variance showed significant effect $(\mathrm{P}<0.01)$ for the interaction between the water depths and mulches on the variables PR, SS and AY (Table 2).

Table 2. Analysis of variance and level of significance by the Tukey's test for the variables pulp resistance (PR), soluble solids (SS) and average yield (AY) of the second watermelon crop cycle.

\begin{tabular}{lrlcc}
\hline \multirow{2}{*}{ Source of variation } & \multirow{2}{*}{ DF } & \multicolumn{3}{c}{ Mean Square } \\
\cline { 3 - 5 } & & \multicolumn{1}{c}{ PR } & SS & AY \\
\hline Water depths (WD) & 3 & $2.40917^{* *}$ & $5.54000^{*}$ & $302.64229^{* *}$ \\
Residue (a) & 12 & 0.39250 & 1.04542 & 0.46146 \\
Mulches (M) & 3 & $2.23583^{*}$ & $1.79333^{* *}$ & $2119.70562^{* *}$ \\
\hline
\end{tabular}

$\mathrm{DF}=$ Degree of freedom; $\mathrm{CV}=$ Coefficient of variation; $*=$ significant at $5 \%$ and $* *=$ significant at $1 \%$ by the Tukey's test. 
Table 2. Continuation.

\begin{tabular}{lcccc}
\hline \multirow{2}{*}{ Source of variation } & \multirow{2}{*}{$\mathrm{DF}$} & \multicolumn{3}{c}{ Mean Square } \\
\cline { 3 - 5 } & & $\mathrm{PR}$ & $\mathrm{SS}$ & $\mathrm{AY}$ \\
\hline Interaction AxB & 9 & $3.91583^{* *}$ & $2.73333^{* *}$ & $446.77840^{* *}$ \\
Residue (b) & 36 & 0.53083 & 0.28542 & 0.33521 \\
Total & 63 & - & - & - \\
\hline CV \% (WD) & - & 4.40 & 10.15 & 1.09 \\
\hline CV \% (M) & - & 5.12 & 5.30 & 0.93 \\
\hline
\end{tabular}

$\mathrm{DF}=$ Degree of freedom; $\mathrm{CV}=$ Coefficient of variation; $*=$ significant at $5 \%$ and $* *=$ significant at $1 \%$ by the Tukey's test.

The pulp resistance (PR) presented a applied, regardless of the use of mulching (Figure 4). decreasing linear response to the amount of water

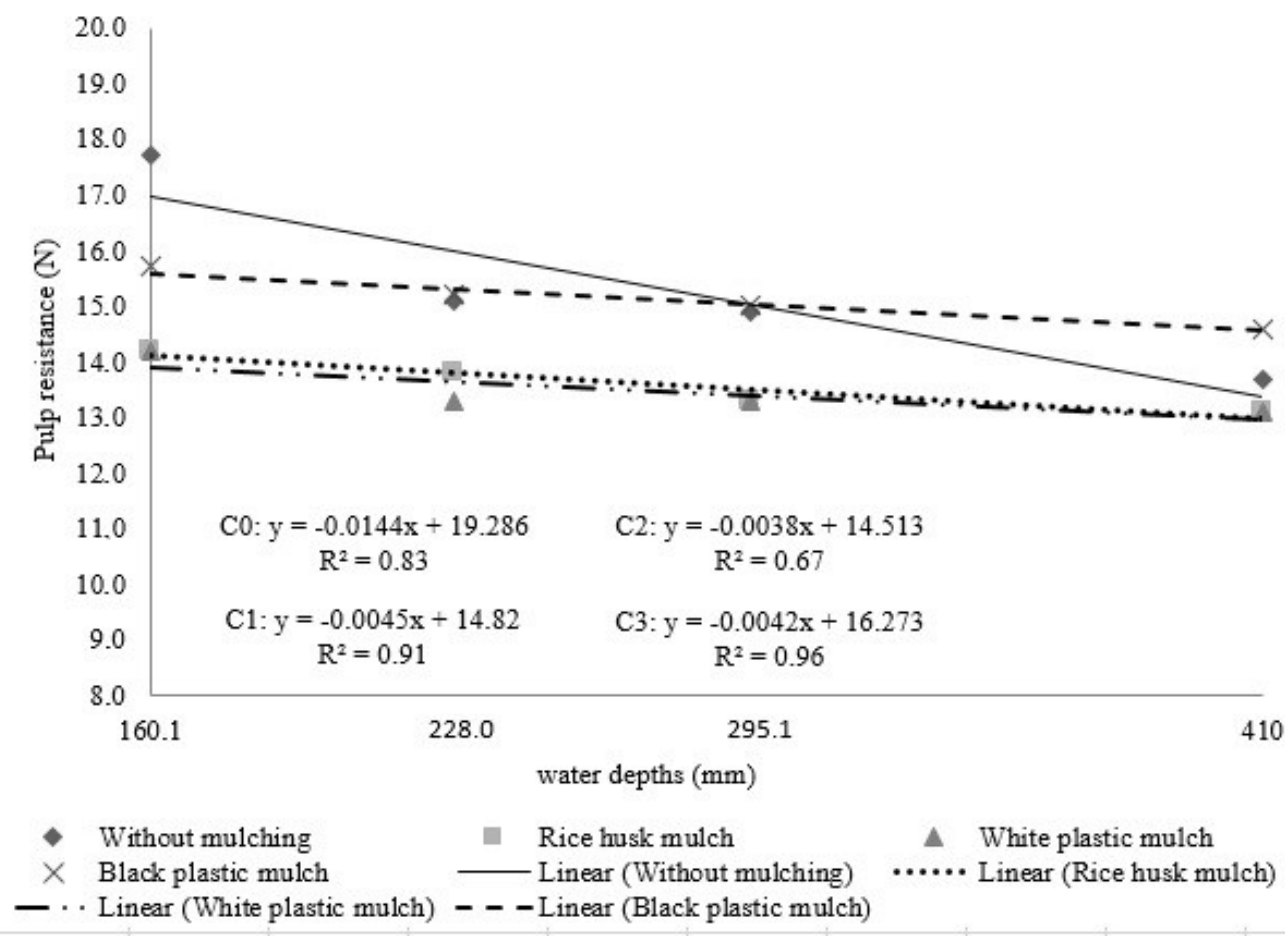

Figure 4. Effects of water depths and mulches on the fruit pulp resistance (PR) during the second watermelon crop cycle.

The greatest RP values were found in the treatments with the lowest water depths, M3 $(14.9 \mathrm{~N})$ and M2 $(14.6 \mathrm{~N})$. On the other hand, the lowest PR values were found in the M1 $(13.3 \mathrm{~N})$ and M4 $(13.1 \mathrm{~N})$, regardless of the mulch type. Carlos et al. (2002), evaluated the watermelon post-harvest under similar climatic conditions and found average PR of $10.9 \mathrm{~N}$.

Similar to the first crop cycle, the lower pulp resistances were related to the greatest water depths. This result was more pronounced in the combinations with mulches, due to the greater soil water retention. According to Negreiros et al. (2005), plastic film mulches provide greater water retention and reduce evaporation from the soil surface, maintaining the moisture until harvest time, regardless of the decrease in the water depth applied, thus, decreasing the fruit pulp resistance.

The fruits from the combination $\mathrm{M} 3 \mathrm{C} 0$ had the highest PR value $(17.7 \mathrm{~N})$. Ramos, Dias and Aragão (2009) evaluated an irrigated watermelon crop and found fruit PR with maximum average of $10.8 \mathrm{~N}$. The combination $\mathrm{M} 4 \mathrm{C} 1$ resulted in the lowest fruit PR $(13.1 \mathrm{~N})$.

The soluble solids (SS) presented a decreasing linear response to the amount of water applied, regardless of the use of mulching (Figure 5). 


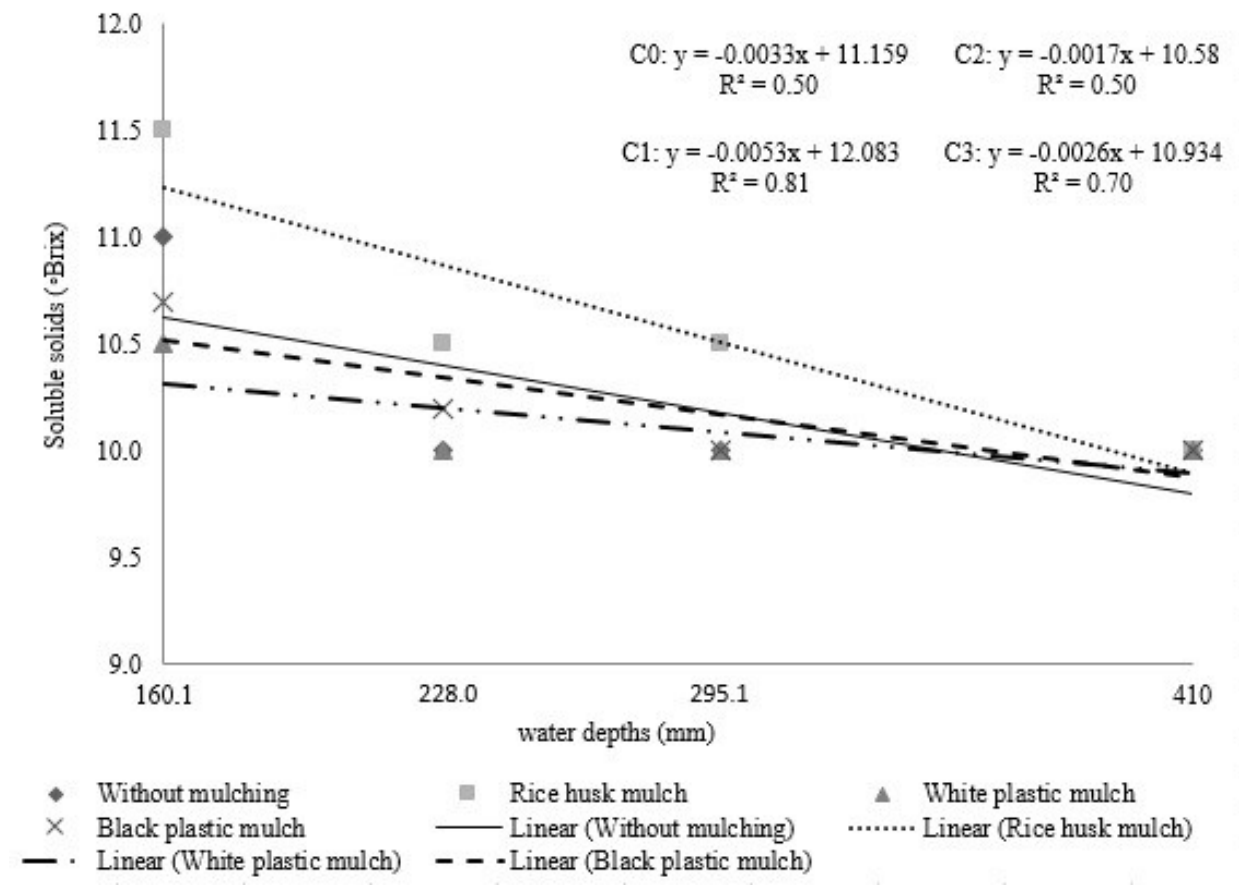

Figure 5. Effects of water depths and mulches on the fruit soluble solids (SS) during the second watermelon crop cycle.

The fruits from the treatments M3 and M2 had the greatest ${ }^{\circ}$ Brix. A similar result was observed by Silva, Cunha and Felipe (2014).

The treatment M1 had fruits with higher ${ }^{\circ}$ Brix when combined with the mulch $\mathrm{C} 1$. The mulches applied in M4 had similar values of SS. Andrade Júnior et al. (2007) found fruits with around $10.4{ }^{\circ}$ Brix under similar weather conditions. However, Sousa et al. (2012) found no significant results with different water depths, indicating that the reducing in the amount of water contributes to maintain the watermelon fruit quality regarding the
SS ( ${ }^{\circ}$ Brix).

The mulches $\mathrm{C} 1$ and $\mathrm{C} 2$ had the best results of SS contents, with the highest ${ }^{\circ} \mathrm{Brix}$, while the lowest fruit ${ }^{\circ} \mathrm{Brix}$ were found in the treatments $\mathrm{C} 0$ (without mulching). These results confirm those reported by Câmara et al. (2007), who found higher SS contents with plastic mulches, compared with treatments without mulching.

The average yield (AY) presented a quadratic polynomial response to the amount of water applied (Figure 6).

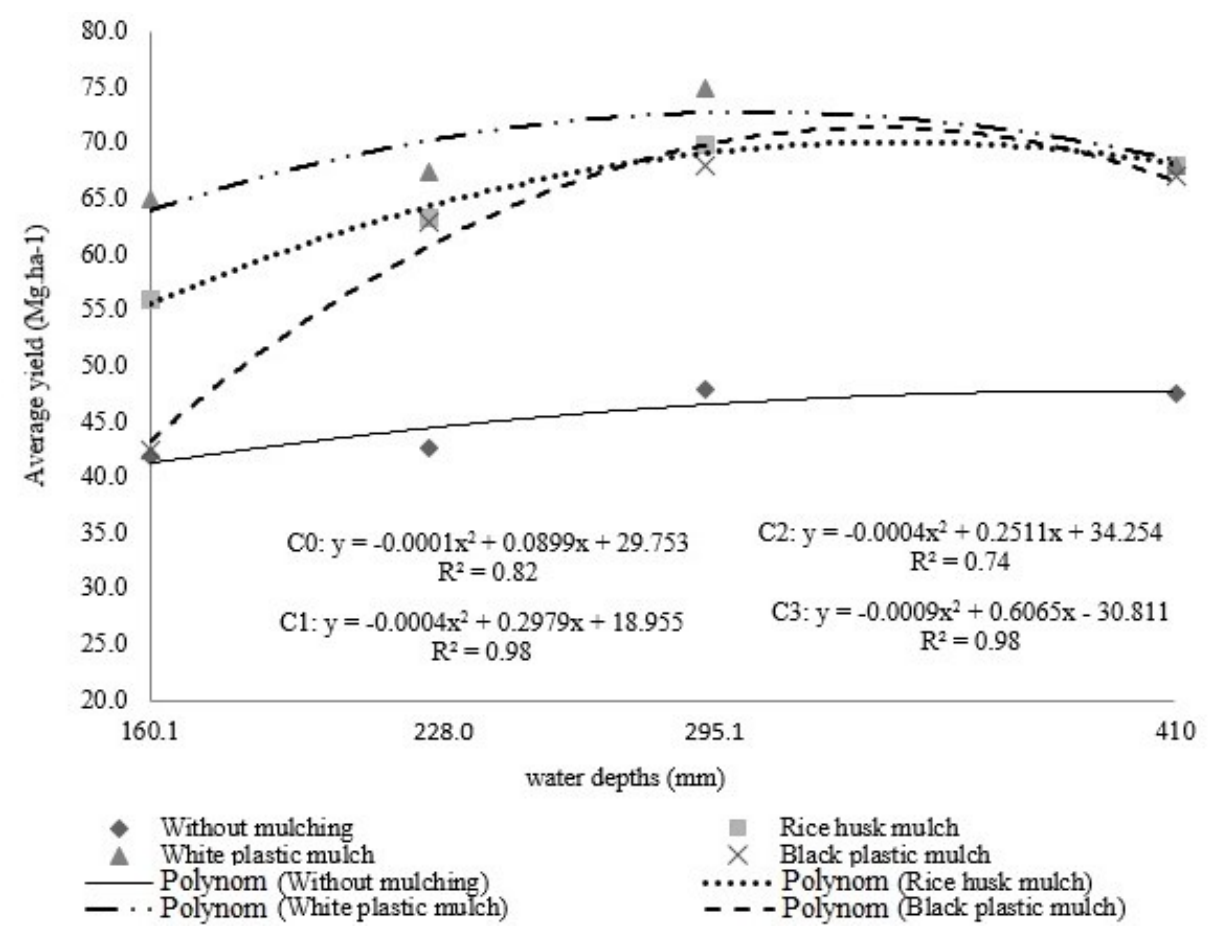

Figure 6. Effects of water depths and mulches on the fruit average yield (AY) during the second watermelon crop cycle. 
The combination $\mathrm{M} 1 \mathrm{C} 2$ resulted in the highest watermelon yield $\left(75.0 \mathrm{Mg} \mathrm{ha}{ }^{-1}\right)$, and according to the regression equation, its maximum yield is $73.66 \mathrm{Mg} \mathrm{ha}^{-1}$, with application of a water depth of $314 \mathrm{~mm}$. Andrade Júnior et al. (2007) found maximum average watermelon yield of 95.28 $\mathrm{Mg} \mathrm{ha}^{-1}$ and minimum of $74.57 \mathrm{Mg} \mathrm{ha}^{-1}$, under similar conditions. The lowest yield of the treatment M1 was found in with the mulch C0 (47.9 $\left.\mathrm{Mg} \mathrm{ha}^{-1}\right)$.

The combination of the lowest water depth (M3) with the soil without mulching (C0) resulted in the lowest fruit yield (41.9 $\left.\mathrm{Mg} \mathrm{ha}^{-1}\right)$. According to Taiz and Zeiger (2013), several factors can affect the fruit growth, however, the cell growth process depends on the cell division and expansion, which require water.

Comparing the results of the first and second watermelon crop cycles, the greater the applied water depth, the greater the yield, considering the extent between M1 and M4, regardless of the use of mulches. Santos et al. (2013) also found a direct and positive correlation between the applied water depth and the watermelon crop yield.

The watermelon grown in soils with mulches had the highest yields, while the lowest yields were found in soils without mulches. These results confirm those found by Silvernail et al. (2006), who reported higher yields in soils with plastic mulches compared with soil without mulching.

The ISAREG model was effective as a strategy for simulations of regulated deficit irrigation, indicating that the irrigation management practiced by local producers of the DIJA in watermelon crops is not appropriated, since they usually apply excessive amounts of water. This was also reported by Saraiva et al. (2013), who carried out simulations with the ISAREG model for evaluating watermelon irrigation management in Acaraú, State of Ceara, Brazil.

\section{CONCLUSIONS}

The irrigation management practiced during the watermelon crop cycle by the local producers of the Irrigation District of Jaguaribe-Apodi (DIJA) in the State of Ceara, Brazil, is not appropriated, since they usually apply more water than the highest water depth determined by the ISAREG model $(100 \%$ of the available water capacity - AWC).

The plants grown under irrigation water depth of $365.20 \mathrm{~mm}$ (M1), i.e., $100 \%$ of the AWC, and soils with mulches of rice husk or white plastic had the highest yields and fruits with better quality of soluble solids and pulp resistance.

\section{REFERENCES}

ALLEN, R. G. et al. Crop evapotranspiration: guidelines for computing crop water requirements. 1. ed. Rome: FAO, 1998. 279 p. (FAO, Irrigation and Drainage Paper, 56).

ANDRADE JÚNIOR, A. S. de. et al. Frequência de aplicação de nitrogênio e de potássio via água de irrigação por gotejamento na cultura da melancia em Parnaíba, PI. Agropecuária Científica no Semi-Árido, Campina Grande, v. 3, n. 1, p. 1-7, 2007.

AZEVEDO, B. M. de. et al. Efeitos de níveis de irrigação na cultura da melancia. Revista Ciência Agronômica, Fortaleza, v. 36, n. 1, p. 9-15, 2005.

BARROS, M. M. et al. Produção e qualidade da melancia submetida à adubação nitrogenada. Revista Brasileira de Engenharia Agrícola Ambiental, Campina Grande, v. 16, n. 10, p. 1078-1084, 2012.

BATISTA, P. F. et al. Produtividade da melancia irrigada por gotejamento submetida a diferentes espaçamentos e lâminas de irrigação. Horticultura Brasileira, Brasília, v. 26, n. 2, p. 5706-5709, 2008.

CÂMARA, M. J. T. et al. Produção e qualidade de melão amarelo influenciado por coberturas do solo e lâminas de irrigação no período chuvoso. Ciência Rural, Santa Maria, v. 37, n. 1, p. 58-63, 2007.

CANTU, R. R. et al. Cultivo de rúcula em túneis com diferentes tipos de cobertura e mulching. Revista Ciência Rural, Santa Maria, v. 43, n. 5, p. 810-815, 2013.

CARLOS, A. L. X. et al. Vida útil pós-colheita de melancia submetida a diferentes Temperaturas de armazenamento. Revista Brasileira de Produtos Agroindustriais, Campina Grande, v. 4, n. 1, p. 29-35, 2002.

CARVALHO, L. C. C. de; BEZERRA, F. M. L.; CARVALHO, M. A. R. de. Evapotranspiração e coeficientes de cultivo da melancia sem sementes. Revista Ciência Agronômica, Fortaleza, v. 39, n. 1, p. 53-59, 2007.

FERNANDES, C. N. V. et al. Frequências de fertirrigação nitrogenada e fosfatada na rentabilidade econômica da melancia. Revista Brasileira de Agricultura Irrigada, Fortaleza, v. 8, n. 3, Fortaleza, p. 270 - 279, 2014.

LACERDA, C. F. Relações solo - água - planta em ambientes naturais e agrícolas do nordeste brasileiro. 1. ed. Universidade Federal Rural de Pernambuco. Recife, PE: UFRP, 2007. 78 p.

LÉO, L. F. R.; HERNANDEZ, F. B. T. A irrigação na agricultura irrigada. 1. ed. São Paulo, SP: 
UNESP, 2007. $165 \mathrm{p}$.

MIRANDA, F. R.; OLIVEIRA, J. J. G.; SOUZA, F. Evapotranspiração máxima e coeficientes de cultivo para a cultura da melancia irrigada por gotejamento. Revista Ciência Agronômica, Fortaleza, v. 35, n. 1, p. 36-43, 2004.

MORAIS, N. B. et al. Respostas de plantas de melancia cultivadas sob diferentes níveis de água e de nitrogênio. Revista Ciência Agronômica, Fortaleza, v. 39, n. 3, p. 369-377, 2008.

NEGREIROS, M. Z. et al. Rendimento e qualidade do melão sob lâminas de irrigação e cobertura do solo com filmes de polietileno de diferentes cores. Horticultura Brasileira, Brasília, v. 23, n. 3, p. 773-779, 2005.

OLIVEIRA, P. G. F. et al. Eficiência de uso dos fatores de produção água e potássio na cultura da melancia irrigada com água de reuso. Revista Brasileira de Engenharia Agrícola Ambiental, Campina Grande, v. 16, n. 2, p. 153-158, 2012.

PEREIRA, L. S. Necessidades de água e métodos de rega. Publicado na Europa e América. 1. ed. Lisboa-Portugal. 2004. 300 p.

RAMOS, A. R. P.; DIAS, R. de C. S.; ARAGÃO, C. A. Qualidade de frutos de melancia sob diferentes densidades de plantio. Horticultura Brasileira, Brasília, v. 27, n. 2, p. 2182-2188, 2009.

SANTOS, G. R. et al. Manejo da adubação potássica e da irrigação no progresso de doenças fúngicas e produtividade da melancia. Horticultura Brasileira, Brasília, v. 31, n.1, p. 36-44, 2013.

SARAIVA, K. R. et al. Aplicação do "ISAREG" no manejo da irrigação na cultura da melancia no Baixo Acaraú, Ceará. Revista Ciência Agronômica, Fortaleza, v. 44, n. 1, p. 53-60, 2013.

SILVA, D. R. M.; CUNHA, C. S. M.; FELIPE, E. A. Aspectos vegetativos e reprodutivos para a cultura da melancia sob diferentes coberturas de solo e níveis de irrigação em Teresina - PI. ACSA Agropecuária Científica no Semiárido, Campina Grande, v. 10, n. 2, p. 96-103, 2014.

SILVA, N. C. et al. Qualidade pós-colheita de melancias para mercado interno sob diferentes espaçamentos entre plantas e lâminas de irrigação. Horticultura Brasileira, Brasília, v. 26, n. 2, p. 5617-5621, 2008.

SILVERNAIL, A.; BOMFORD, M.; HARVEY, B. Alternatives to plastic mulch for organic watermelon production. Kentucky Academy of Science Meeting,
Agicultural Sciences Section. Morehead, KY. 2006.

SOUSA, J. R. M. et al. Efeito do estresse hídrico sobre características de pós-colheita da melancieira. ACSA - Agropecuária Científica no Semi-Árido, Campina Grande, v.8, n. 2, p. 46-53, 2012.

SOUSA, V. F. et al. Irrigação e fertirrigação em fruteiras e hortaliças. 1. ed. Brasília, DF: Embrapa Informação Tecnológica, 2011. 771 p.

TAIZ, L.; ZEIGER, E. Fisiologia vegetal. 5. ed. Porto Alegre, RS: ArtMed, 2013. 820 p. 